\title{
CENTRAL EUROPEAN IMPULSES IN EASTERN EUROPE IN THE EARLY SECOND MILLENNIUM BC ${ }^{1}$
}

\author{
S T A N I S L A V G R I G O R I E V
}

\begin{abstract}
Eastern European cultures of the beginning of the $2^{\text {nd }}$ millennium BC, first of all, Babino and Abashevo, to a lesser extent Lola and Sintashta, have some Central European inclusions, indicating migration from west to east during this period. This makes it possible to establish chronological relations of the complexes of Eastern Europe, the Urals and Kazakhstan at the transition from the Eurasian Middle to Late Bronze Age with the Central European Early Bronze Age ${ }^{2}$ complexes. Most of the parallels between these regions are dated within broad chronological frameworks. However, comparison of the whole complex of common features allows determining the initial date of the discussed Eastern cultures within phase A1c of Central Europe, which is in a good agreement with radiocarbon dates. Analysis of these materials shows that components formed on the post-Bell-Beaker and post-Corded basis penetrated into Eastern Europe. At the same time, there was a flow from the south, and it is possible that it reached Central Europe.
\end{abstract}

Keywords: Sintashta culture, Babino culture, Reinecke chronology, Central European analogies, Early Bronze Age.

\section{INTODUCTION}

Several years ago, I proposed synchronization of the early stages of the Sintashta and Babino cultures with the phase A1b, based on the similarity of Babino materials with the Untervölbling and Straubing cultures in Central Europe and an idea of their formation as a result of eastern impulses (Grigoriev 2002, 388-390; 2018b, 44). Later, R. O. Lytoynenko (2009; 2013) reversed the direction of these pulses, but left the same date. In addition, in our constructions we used the older two-term scheme for dividing the older EBA phase, and not the modern three-term one. Therefore, we will try here to determine the chronological frameworks of particular types, and the possibilities that they provide for justifying synchronization with Eastern European cultures. We will discuss also those types that, being typical for Central Europe, did not appear in Eastern Europe, since this may be an additional basis for chronological interpretations. The period under discussion was dynamic, with a complex interaction of multidirectional impulses and local components. Here we avoid this and discuss only European parallels in eastern cultures with the aim to determine their position in the chronological system of P. Reinecke.

\section{PERIODIZATION OF THE CENTRAL EUROPEAN EBA}

In recent years, phase A1c has appeared inside Reinecke's stage A1, in addition to phases A1a and $\mathrm{A} 1 \mathrm{~b}$, which makes it possible to clarify the chronology of the eastern complexes. In general, the periodization of the Central European EBA is given in the table 1 which is based on works of only some authors (Bátora 2018; Jaeger/Kulcsár 2013; Kiss et al. 2015; Neugebauer 1991). A real situation is more complex, since some cultures existed longer within individual areas, many their stages do not strictly correspond to the periods in a scheme with horizontal lines. And in the European chronological studies there are many discussions about this, which we not discuss here.

\section{BURIAL RITE}

R. O. Lytvynenko drew an important conclusion about the similarity of funeral rite of Babino culture with that of the cultures in southern Germany and Austria: a presence of 'bipolar opposition' based on gender. For the early stage of Babino culture, men burials are contracted on the left side oriented west, and women are on their right side oriented east (Lytoynenko, R. A. 2009, 7). This rite is actually typical of the burials of many EBA groups in this region: Straubing, Untervölbling, Adlerberg, Ries, Neckar, Singen, Mureș. Moreover, men are always on their left side oriented north, and women on the right side oriented south. And it was probably a heritage of the Bell-Beaker culture with its contracted burials (men on the right side oriented south, and women on the left side

\footnotetext{
1 This paper was written in the frame of project: 'Local processes and eastern influences at the transition from the Early Bronze Age to the Middle Bronze Age in Central Europe’ by Slovenská akademická informačná agentúra.

2 Further in the text abbreviations will be used: Early Bronze Age - EBA, Middle Bronze Age - MBA, Late Bronze Age - LBA.
} 


\begin{tabular}{|c|c|c|c|c|c|c|c|c|c|}
\hline $\begin{array}{l}\frac{0}{0} \\
\frac{\pi}{0} \\
0\end{array}$ & 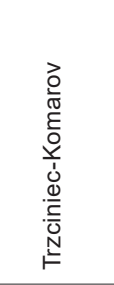 & 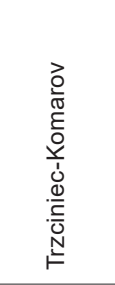 & 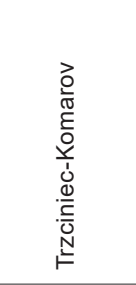 & 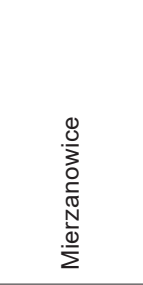 & 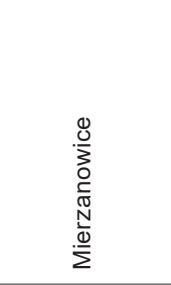 & 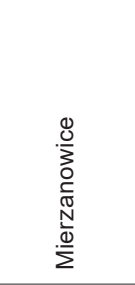 & 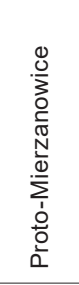 & 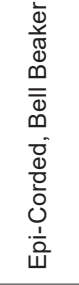 & 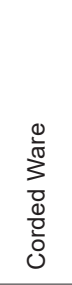 \\
\hline 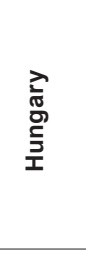 & 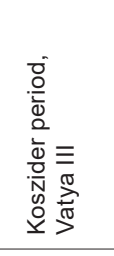 & 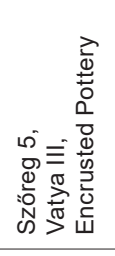 & 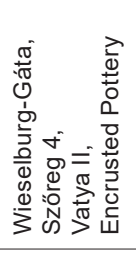 & 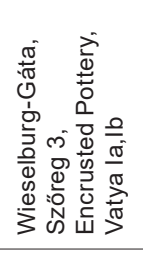 & 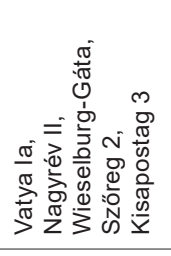 & 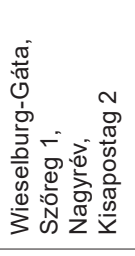 & 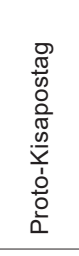 & 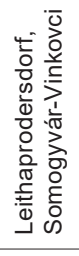 & 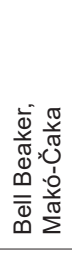 \\
\hline 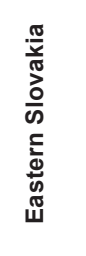 & 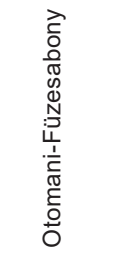 & 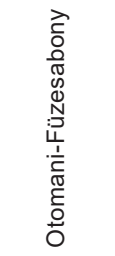 & 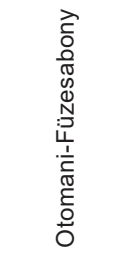 & 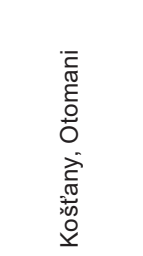 & 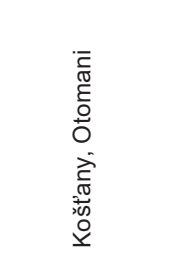 & 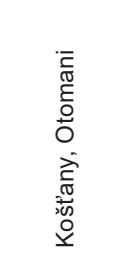 & 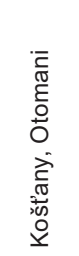 & 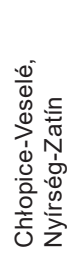 & 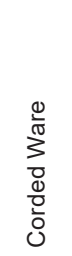 \\
\hline 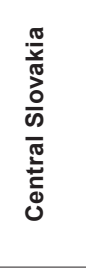 & 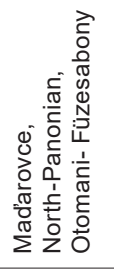 & 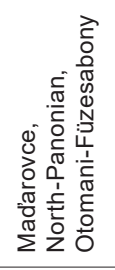 & 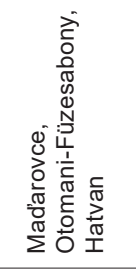 & 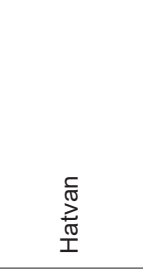 & 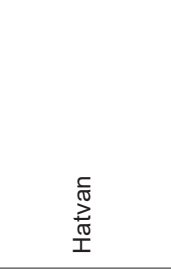 & 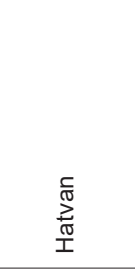 & 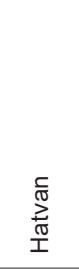 & 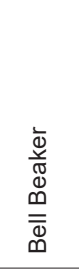 & 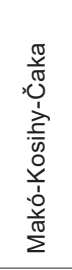 \\
\hline 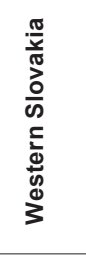 & 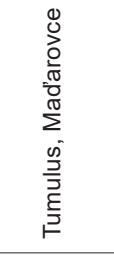 & 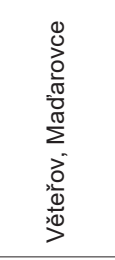 & 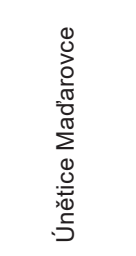 & 造 & 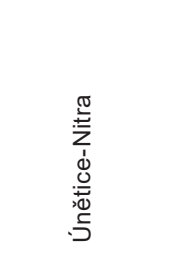 & $\frac{\widetilde{\pi}}{\bar{z}}$ & $\frac{\sqrt[a]{5}}{\frac{5}{z}}$ & 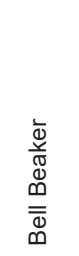 & 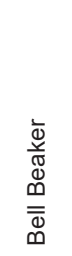 \\
\hline 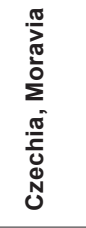 & 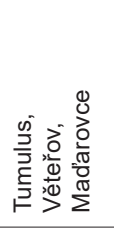 & 总 & 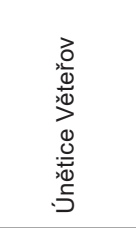 & 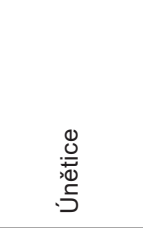 & 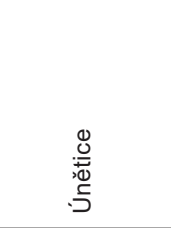 & 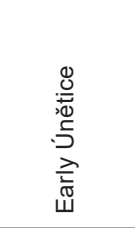 & 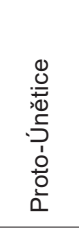 & 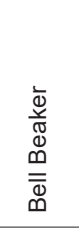 & 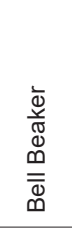 \\
\hline 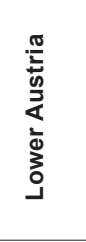 & 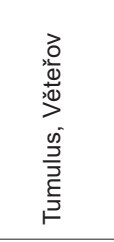 & 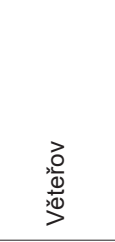 & 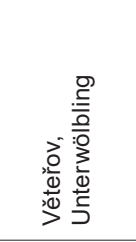 & 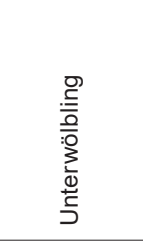 & 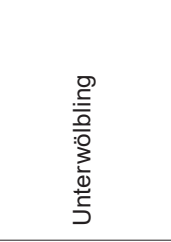 & 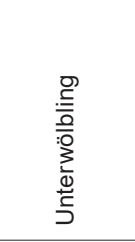 & 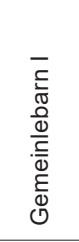 & 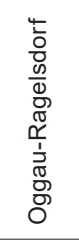 & 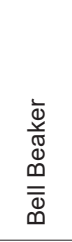 \\
\hline 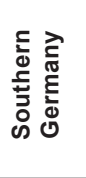 & 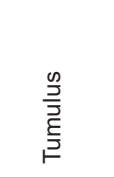 & $\begin{array}{l}\text { ᄃे } \\
\text { 遈 }\end{array}$ & $\begin{array}{l}\text { 总 } \\
\text { 这 }\end{array}$ & 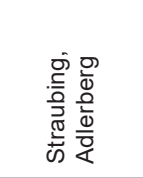 & 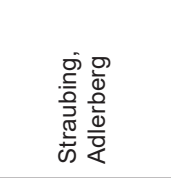 & 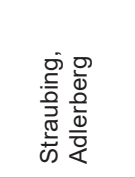 & 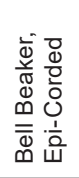 & 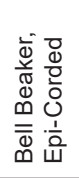 & 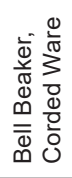 \\
\hline 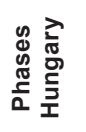 & $\stackrel{m}{\stackrel{m}{\infty}}$ & $\stackrel{m}{\stackrel{m}{m}}$ & $\begin{array}{l}\stackrel{N}{\overleftarrow{m}} \\
\stackrel{m}{\Sigma}\end{array}$ & 㐫 & 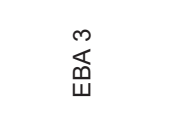 & 孞 & $\begin{array}{l}\stackrel{0}{N} \\
\underset{\mathbf{m}}{W}\end{array}$ & $\begin{array}{l}\stackrel{\mathbb{N}}{\mathbb{N}} \\
\stackrel{\Phi}{\Psi}\end{array}$ & $\begin{array}{l}\stackrel{\mathbb{N}}{N} \\
\mathbb{1} \\
\stackrel{9}{\Psi}\end{array}$ \\
\hline 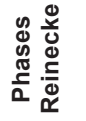 & $\bar{\infty}$ & $\underset{\sim}{\mathbb{~}}$ & $\underset{\sim}{\stackrel{\sim}{<}}$ & $\stackrel{\mathbb{N}}{\underset{\leftarrow}{\leftarrow}}$ & $\frac{0}{\alpha}$ & $\frac{\Omega}{8}$ & $\frac{\pi}{4}$ & \& & 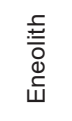 \\
\hline
\end{tabular}


orientated north). But there is a difference in the discussed groups from Babino: all orientations are meridional. Individual burials with a latitudinal orientation are known only in the northern groups of the region: Ries, Adlerberg and Neckar (Bertemes/Heyd 2015, 6; Heyd 2007, 94; Lutteropp 2009, 328, 330, 336, 339-348, 355, 358; Neugebauer 1991, 83-86). Possibly this may be explained by an influence of the Corded Ware cultures in which this orientation dominated, but the gender opposition was also typical: men were buried on the right side, and women on the left, all facing south (Dresely 2004, 99, 100, 102, 105-107; Heyd 2004, 187; Neugebauer 1991, 86). An identical rite is known in the Chłopice-Veselé culture in southern Poland and Slovakia (Bátora 2018, 267).

Studies of the Jelšovce cemetery in Slovakia showed that the latitudinal orientations with significant deviations were typical of the Nitra and Unnetice cultures, which is closer to the Babino culture rite. But men were buried on the right, and women on the left side, all facing south, which was typical of the cultures of this area (for example, Nitra - Vladár 1973, 125, 128), although in the indigenous Únětice area, in Moravia, both sexes lie on the right side. Bipolarity and sexual demorphism were characteristic there for neither Proto-Únětice nor classical Únětice stage (Peška $2005,316)$. In the Jelšovce cemetery there is only a small group of Nitra burials facing north (Bátora 2000, 451, 452, 463, 464, 478), and this is the only relatively accurate analogy to the Babino culture rite in Central Europe.

Thus, today we do not know exact analogs of the Babino culture funeral rite in Central Europe, which does not allow us on this basis to link its sources to a particular territory or chronological period. But even in Europe, the discussed features have variations. Therefore, the strict parallel is only the fact of the presence of bipolar burials. It can be assumed that, since the meridional orientations were typical of the cultures inherited the Bell-Beaker traditions, and the latitudinal orientations can be traced back to the Corded Ware culture tradition, the Babino culture rite could be associated with one of the epi-Corded cultures. But, since we are talking about the transfer of the general principle, its date in the European space is extremely wide, covering the late Eneolithic and a significant part of the EBA $(\mathrm{A} 0-\mathrm{A} 2 \mathrm{~b})$, which does not allow using this feature in chronological studies. However, this parallel is very important from the point of view of the interpretation of the borrowings from Central Europe, which will be discussed below. The transfer of social and gender relations, reflected in the cult practice (and, therefore, included in some mythological system), is impossible without the migration.

\section{Ceramics}

It should be noted that so far we have not been able to find anything in common with the Central European ceramic complexes in Sintashta, Babino and Lola ceramics. The Near Eastern and Eastern European components are more expressed in the Sintashta culture ware, the Eastern European and Caucasian components in the Lola ware, and the Eastern European components in Babino culture. The only exception is the Abashevo culture. R. A. Mimokhod $(2018,41)$ quite rightly determined that it was formed simultaneously with the post-Catacomb block, and its funeral ritual, costume, set of copper ornaments and ceramics are based on Central European traditions. For ceramics (Fig. 1:31) we can find very close parallels in the late Bell-Beaker culture. Probably, in general this conclusion is correct, but it is not based on a detailed comparison of ceramic complexes with different periods of the Bell-Beaker culture, but on already existing ideas about chronology. In fact, in the Bell-Beaker culture of Moravia and Austria, ornamental motifs identical to those of Abashevo culture are more characteristic for the Eneolithic stages A and B and less for stages C and $\mathrm{D}$ of the final Eneolithic and the transition to the EBA. So far, these stages have no reliable stratigraphic confirmation (Metzinger-Schmitz 2004, 157, 236, fig. 63; pl. 41b). But a vessel with the 'Abashevo' decoration is present in a burial of the Vatya culture I period (Vicze 2011, 84). This means, the conclusion about the connection of Abashevo culture ceramics with the Bell Beaker culture ceramics or cultures formed on its basis is quite fair, but without detailed comparisons it gives a date from the late Eneolithic to the beginning of the younger EBA phase.

For Babino and Sintashta cultures, against the background of missing direct analogies to form and ornamentation of ceramics, the only possible parallel are applied cordons, due to which Babino culture was previously called 'Multi-Cordoned Ware culture' (Fig. 1: 7, 8). For the Sintashta culture (and, probably, for late Catacomb complexes), some southern impulses could be a source of the cordons (Grigoriev 2002, 94-96), but for the Babino culture a Central European source is partly admissible (although a late Catacomb source is more probable). But cordons are present on the Central European ware from the final Eneolithic to the MBA (Fig. 2: 43, 44). Therefore, without a detailed comparison of Babino culture ceramics with Central European ware, we cannot use this feature for dating. 


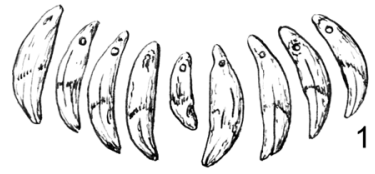

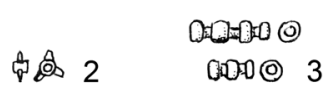

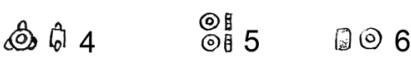
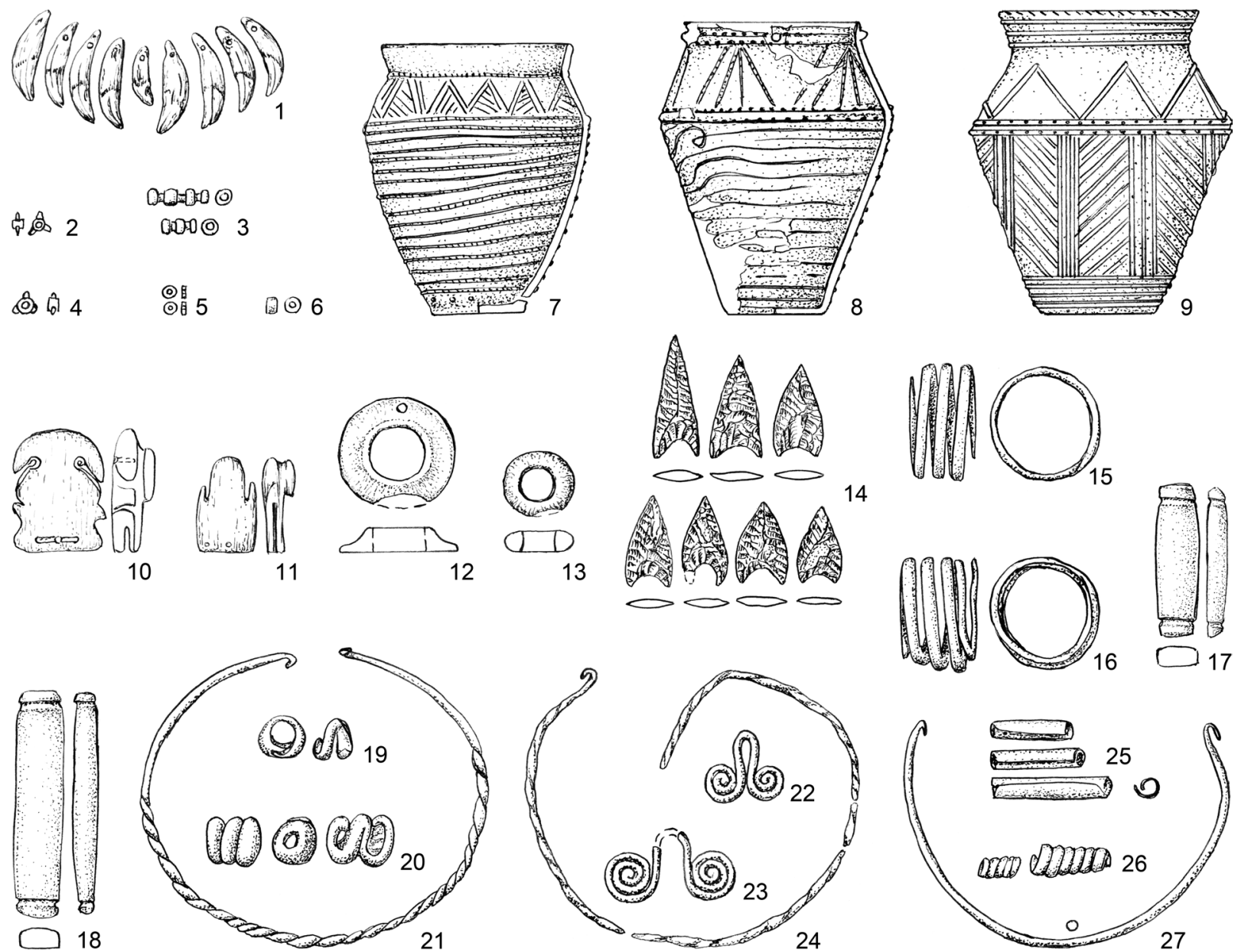

(0) 28
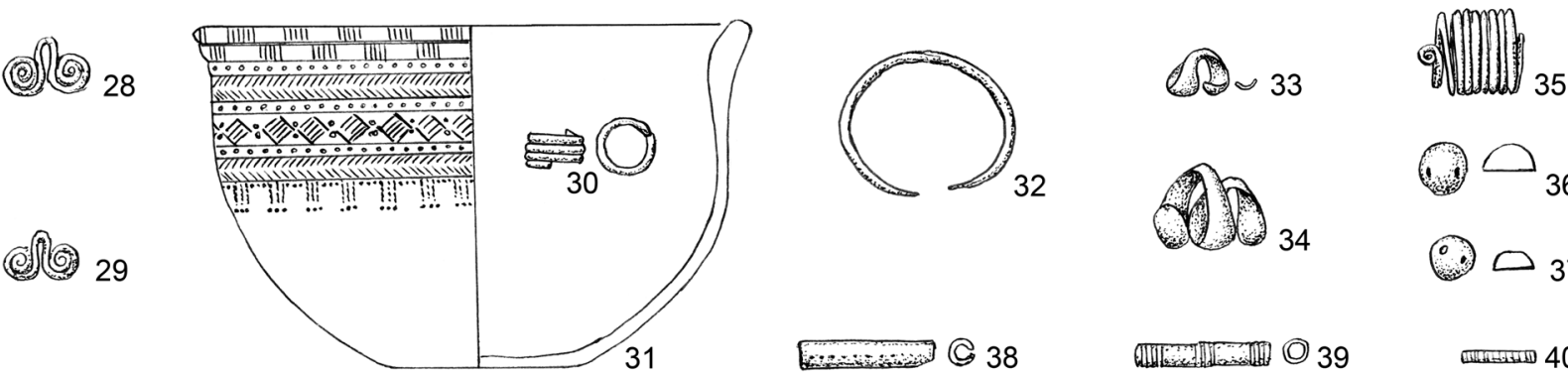

29
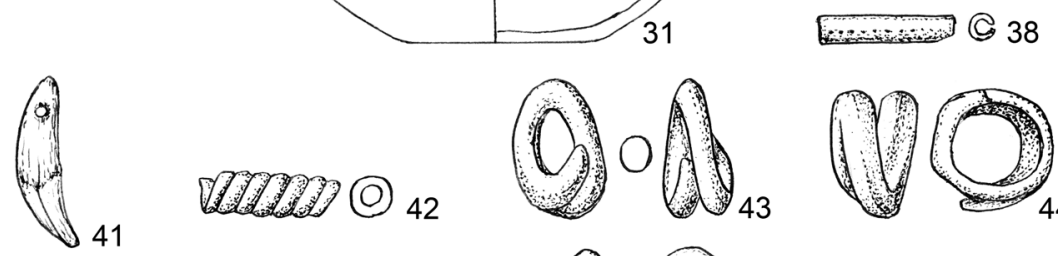

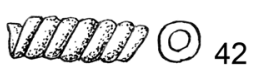
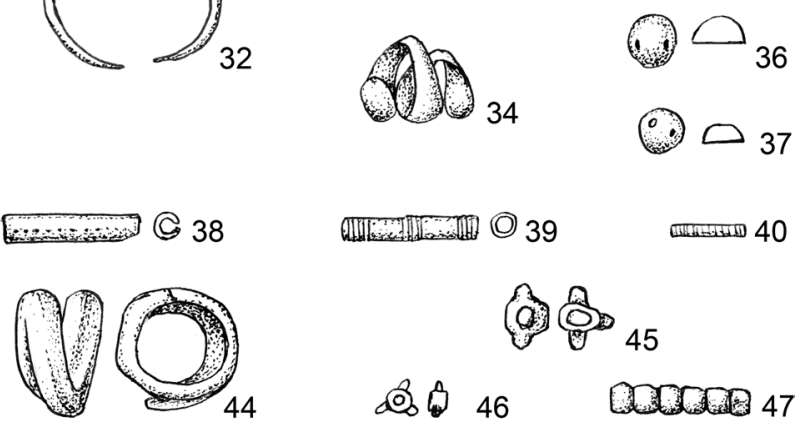

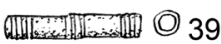

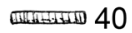

\section{웡요 45}

ब. 46

DOCAd 47
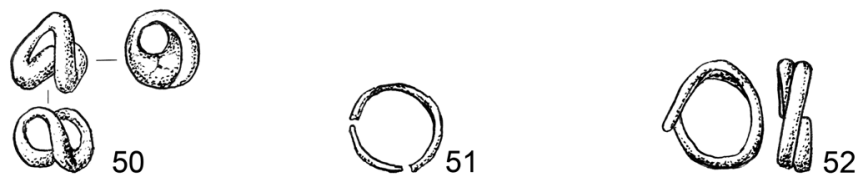

๑ํำ

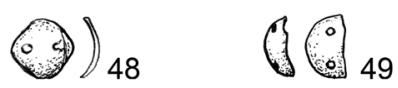

50

Fig. 1. Artifacts of Babino (1-27), Abashevo (28-40), Lola (41-49) and Sintashta (50-53) cultures. 1-41 - pendants of animal fangs; 2, 4, 45, 46 - faience beads with protrusions; 3, 47 - faience segmented beads; 5, 6, 53 - round and cylindrical faience beads; 7-9, 31 - ceramic vessels; 10, 11 - bone figured buckles with a hook; 12, 13 - round bone buckles; 14 - flint arrowheads; 15, 16 - spiral bracelets; 17, 18 - stone wristguards; 19, 33, 43, 44, 50 - grooved pendants in 1.5 revolutions; 20, 34 - grooved pendants in 1.5 revolutions with a reverse loop; 21, 24, 27 - neck rings; 22, 23, 28, 29 - glass-shaped pendants; 25, 38, 39 - tube-shaped pendants; 26, 40, 42 - spiral pendants; 30, 35, 52 - spiral finger rings; 32 - bracelet from wire; 36, 37, 48, 49 - hemispherical platelets with two holes (made by O. Orlova after Grigoriev 2015; Lytvynenko 


\section{Metal objects}

For European metallurgy of the A1 period, the so-called Blech-und Drahtindustrie was typical, when most objects were made of wire and foil. One of the most striking manifestations of this industry are ornaments made of foil in the form of willow leaf (Fig. 2: 1). Chronological differences between them are not great, but for the earlier forms, a less pronounced middle rib is characteristic than for the later ones. They are found in the context of several cultures: Chłopice-Veselé, Nitra, Koštany (Vladár 1973, pl. I-VI, and others; Bátora 2018, 171, 177). For later cultures, these objects are not typical, and are completely absent in the Babino, Lola, Abashevo and Sintashta cultures, which indicates their later chronological position. This is confirmed by the presence of similar objects in the earlier Fatyanovo culture, which was formed under the European influence (Kuzmina 2002), therefore it seems to be doubtful the date within the framework of A1b phase and earlier.

Pendants, bracelets and rings made of wire were widely used in Central and Eastern Europe (Fig. $1: 30,52 ; 2: 4-10)$. There is a great ty pological variety of these simple forms. But the main differences can be identified by several features: the manufacture from single or double wire, the presence of one to three revolutions, reverse loop, closed ends, or they go over each other. Simple objects from wire with round cross-section appeared in the late Eneolithic and existed throughout the Bronze Age (Bertemes/ Heyd 2015, fig. 5). Moreover, already in the early stages there are rings and pendants of double wire with the reverse loop and without it. They are present throughout the Nitra culture, in the Koštany culture, starting from the proto-Koštany phase and in other epi-Corded cultures (Mierzanowice, Stryżów), and they coexisted with simple forms (Bátora 1983, pl. IV; 2000, 321; 2018, 171; Vladár 1973, pl. I-VI etc.).

The same situation with the coexistence of different types preserved in the Slovakian Únětice culture (Bátora 2000, 353; Chropovský 1960, 63, fig. 27: 11-14), and in phase Ia of the Vatya culture in Hungary (Bóna 1975, 50). Simple finger rings and ring pendants in two and three revolutions of wire are found in the Dunaújváros-Duna-dülő cemetery in Hungary in burials of several stages: Kisapostag culture, Vatya I and II (Vicze 2011), and also in the Szőreg and Wieselburg culture (Bóna 1975, 100, 245) and Únětice-Mad’arovce graves (Vladár 1973, pl. XXXIV). But at the same time, there are objects of double wire in Únětice culture burials (Podborský 2004, 185, fig. 3), bracelets and rings of double wire with the reverse loop in the Unětice-Madarovce complexes (Vladár 1973, pl. XXXIV). And later, in the Mad'arovce culture burials of the Jelšovce cemetery in Slovakia, single-wire pendants coexist with double-wire pendants with the reverse loop (Bátora 2000, 409).

In the east, in Babino culture, rings from single or double wire did not appear. Further, in Abashevo culture, there are various rings from one wire, but we do not know rings from double wire, However, the existence of all these types from the final Eneolithic to the end of the EBA precludes their use in chronological studies.

Copper spiral pendants, which are present in Babino, Lola, Abashevo and Voronezh complexes (Fig. 1: 26, 40, 42), are the typical Central European type penetrated into Eastern Europe during this period (Lytvynenko, R. O. 2013, fig. 2: 21, 23; Mimokhod 2012, fig. 73; Pryakhin/Sinyuk 1983).

Unfortunately, this type existed for a long time (Fig. 2: 26-29). It first appeared in some Danube cultures in the Late Eneolithic (Bertemes/Heyd 2015, fig. 5). But on the Middle Danube they are not typical of the Nitra culture, and they appeared in the cultures of Únětice and Wieselburg. The earliest ones are known in burials of the Nitra-Únětice transitional phase (Bátora 2000, 361; 2018, 172; Chropovský 1960, 68, fig. 27: 1), being present further in the later Únětice-Madarovce and Madarovce complexes, although in the latter they are rare (Bátora 2000, 361; 2018, 173; Vladár 1973, pl. XXXIV). In eastern Slovakia, this type is known in the Koštany-Otomani phase (Bátora 1983, pl. IX). Therefore, the time of this type existence covers the entire EBA (A0-A2), but they are most typical for the period A1c-A2b. However, it is difficult to rely on this range, since in Austria spiral pendants are present throughout the EBA (Neugebauer 1991, fig. 7: 1, 2).

To the south, in Hungary, spiral pendants are present from the beginning of the EBA and in the MBA (Bóna 1975, 69, 100, 159, 244; Dušek 1960, fig. 4; Polla 1960, 337, fig. 15; Vicze 2011). The later sites (Vatya II, Füzesabony and North-Pannonian) are characterized by long pendants, often from forged wire (Bátora 2018, 191; Bóna 1975, 54), but sometimes these are also found in the period of Vatya I (for example, Vicze 2011, pl. 55; 59). The wide distribution of spiral pendants, rather than single finds, begins since the period Vatya Ia (Bóna 1975, 49, 50). If we rely on the fact that short pendants are characteristic of Eastern European cultures, and also on the fact that they are most characteristic of the $\mathrm{A} 1 \mathrm{c}-\mathrm{A} 2 \mathrm{~b}$ period in Slovakia and Hungary, we can take this range as a basis, but it would be more correct speak about the A1 period in general.

Another type, tube-shaped pendants, is present in sites of the Babino and Abashevo cultures (Fig. 1: 25, 38, 39; Mimokhod 2018, fig. 5: 15, 16; Lytoynenko, R. O. 

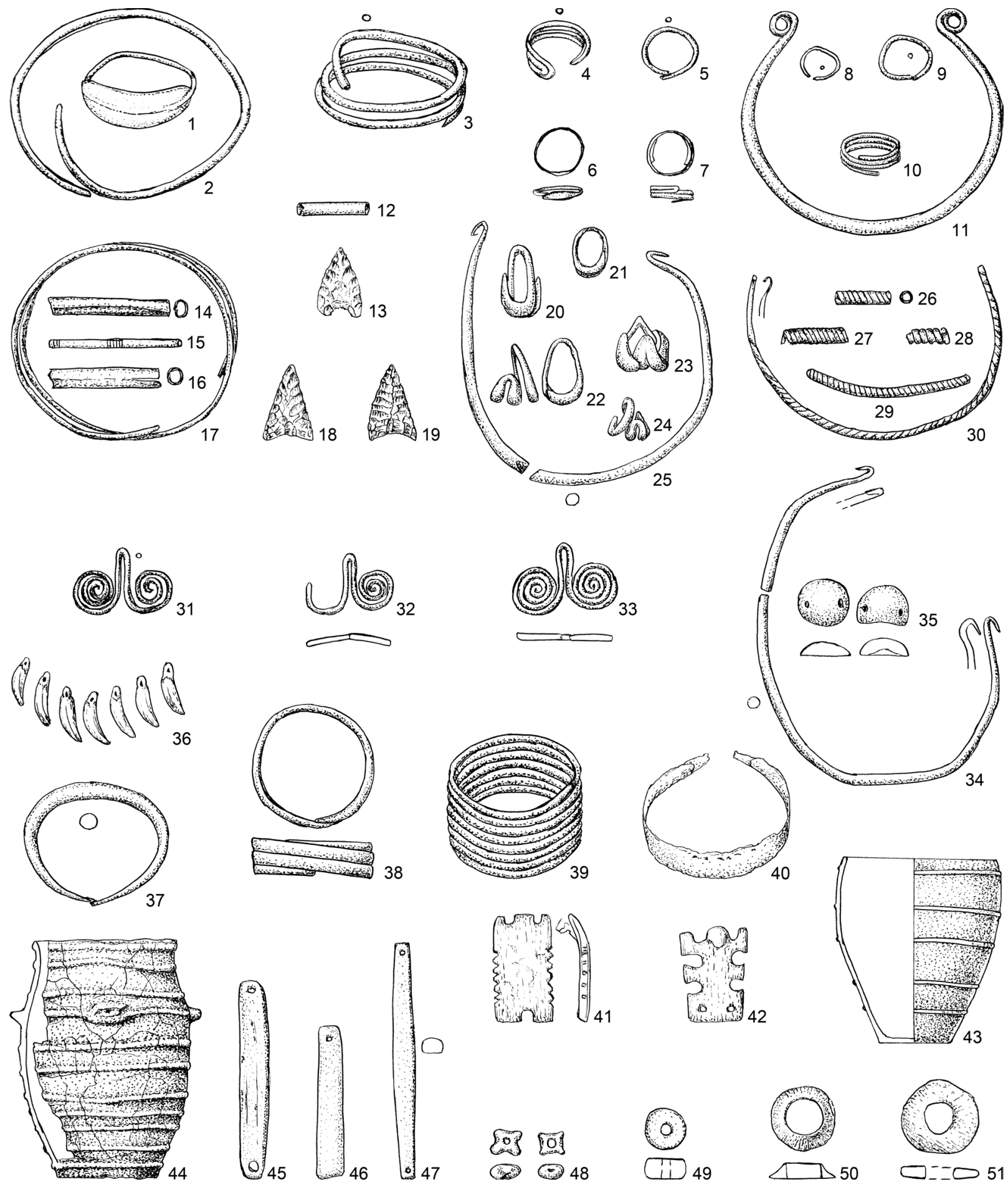

Fig. 2. Artifacts of Central European cultures: Nitra (1-5, 12, 13, 46, 47), Únětice $(6-8,10,11,15,17,19,20,23,27,36$, 40, 45), Mad’arovce $(9,21,37,39,41,42,51)$, Kisapostag (14, 28), Vatya (16, 29, 31-33, 35, 38), Bell-Beaker (18), Nagyrév (22, 48, 49), Koštany (24), Hatvan, Vel'ká Lomnica (25, 30, 34), Gemeinlebarn I (26), Polada (43), Rhône (44) and Adlerberg (50). 1 - pendant in the form of willow leaf; 2, 17 - neck rings from wire; 3, 38, 39 - spiral bracelets; 4-10 - rings from wire; 11 - neck ring with looped ends; 12, 14-16 - tube-shaped pendants; 13, 18, 19 - flint arrowheads; 20, 21 - grooved pendants in 1.5 revolutions; 22-24 - grooved pendants in 1.5 revolutions with a reverse loop; 25, 30, 34 - neck rings from Vel'ká Lomnica; 26-29 - spiral pendants; 31-33 - glass-shaped pendants; 35 - hemispherical platelets with two holes; 36 - pendants of animal fangs; 37 - bracelet from a rod; 40 - diadem; 41, 42 - bone buckles; 43, 44 - ceramic vessels; 45-47 stone wristguards; 48 - faience beads with protrusions; 49 - round faience beads; 50,51 - round bone buckles (made by O. Orlova after Bátora 2018; 2000; Budziszewski/Włodarczak 2010; Furmánek/Veliačik/Vladár 1999; Jiráň 2008; Lytvynenko 2013; Neugebauer 1991; Novotná 1984; Vicze 2011). 
2013, fig. 2: 27-29). In Central Europe (Fig. 2: 12, 14-16), this type appeared in the late Eneolithic (Bertemes/Heyd 2015, fig. 5), and in the Slovakian EBA it is present in the Nitra and Nitra-Únětice complexes (Vladár 1973, pl. I-III; VI and others; Bátora 1983, pl. VIII; 2018, 191). This type is then common in the Únětice, Koštany (classical phase) and Wieselburg cultures, and in the Untervölbling and Straubing groups (Bátora 2000, 360, 361; Chropovský 1960, 68; Jiráň 2008, fig. 26; Veliačik/Masnicová 2004, 177). To the south, in Hungary, it is present in complexes of the Wieselburg culture and Szöreg group (phases 1 and 2), Nagyrév, Kisapostag, Vatya (I, II) and Encrusted Ware cultures (Bóna 1975, 49, 50, 54, 100, 217, 244; Vicze 2011). Thus, the time of its existence covers the entire EBA (A1-A2), and it is not applicable to solving chronological problems.

In the Sintashta, Abashevo and Babino cultures, and in the late Catacomb complexes there are grooved pendants in 1.5 revolutions (Fig. 1: 19, 33, 43, 44, 50; Grigoriev 2015, fig. 6-22: 1-10; Lytvynenko, R. O. 2011, fig. 3: 6-9; Mimokhod 2012, 168-171; 2018, fig. 5: 15, 16). In Central Europe, similar objects (Sibinian or Siebenbürgen pendants) are well known (Fig. 2: 20, 21). In Slovakia, the earliest are present in the Koštany culture, and then in all subsequent cultures of the EBA: Únětice, Únětice-Mad’arovce phase, Mad’arovce, Otomani-Füzesabony (Bátora 2018, 173). In Moravia and Lower Austria, they are known in the context of the classical Únětice culture and Unterwölbing group (Bátora 2000, 409-411; Jirán̆ 2008, fig. 26). In Hungary, the earliest similar pendant was found in a burial of the Nagyrév culture of the Dunaújváros-Duna-dúlő cemetery (Vicze 2011, pl. 3), and similar ones are found in the Vatya Ia complexes (Bóna 1975, 50). They are well represented in the later complexes of Füzesabony, Wietenberg, and Encrusted Ware cultures (Bóna 1975, 159, 185, 218; Polla 1960, 337, fig. 15). Thus, they existed from phase A1b (or A1c), and partly in the MBA. A variation of this type, pendants with a reverse loop (Fig. 1: 20, 34; 2: 22-24), which R. A. Mimokhod compares in the Abashevo and Central European complexes (Mimokhod 2018, fig. 5), are found in a burial of the Vatya I period in Hungary (Vicze 2011, pl. 46), and in the Koštany-Otomani phase in Eastern Slovakia (Bátora 1983, pl. V). This Vatya phase can be synchronized with the A1c-A2a phases.

Grooved bracelets are common in the Sintashta culture (Grigoriev 2015, fig. 6-21), and in Abashevo culture there are wire bracelets with different crosssections (Fig. 1: 32). In Central Europe, grooved bracelets are unknown, and wire bracelets appeared already in the Chłopice-Veselé culture and the early phase of Nitra, then existing in the EBA cultures (Únětice and Mad’arovce), disappearing by the end of this period (Bátora 2018, 177, 178). Thus, these objects are dated by the phases $\mathrm{A} 1-\mathrm{A} 2$, and it is difficult to use them for dating. In the Gemeinlebarn F cemetery in Austria (its early phase is represented by Unterwölbing culture burials, the late by Věteřov-Mad’arovce komplex) there are bracelets with round, oval, pointed-oval, D-shaped, rhombic and triangular cross-sections. More simple bracelets are usually earlier. Bracelets with sharp ends and round and oval cross-sections appeared for the first time in phase A1b, but in general this category of finds is not appropriate for precise dating (Neugebauer 1991, 30, 31). Nevertheless, they are a good parallel to the Abashevo culture objects.

Spiral finger rings and bracelets are known in the context of Babino and Abashevo cultures (Fig. 1: 15, 16, 30, 35; Lytvynenko, R. O. 2013, fig. 2: 16, 17). In Central Europe, spiral bracelets appeared at the end of the Eneolithic (Chropovsky 1960, 64). Moreover, analogues of the Babino bracelets made of thick wire from the Aleksandrovsky hoard are found in the Proto-Únětice culture burial 56 of the Pavlov cemetery dated to 2210-2130 BC (Peška 2005, 315, fig. 58). Bracelets made of thick round or oval wire of the Wieselburg culture (Bóna 1975, 244) and Vatya I period (cf. figs. 1: 15, 16 and 2: 38) can be a definite analogy. But the problem is that different forms of thick spiral bracelets from wire existed, starting from the Nitra, Kisapostag and Vatya I cultures, and further in the Nitra-Únětice phase, Únětice culture, in the Únětice-Madarovce and Koštany-Otomani phases (Bátora 2000, 353; Chropovský 1960, 64; Vicze 2011, pl. 13; 52). In the Szőreg group in Hungary, from the phases 1 and 2, bracelets with 3-5 revolutions appeared. In the later Szőreg group 4 and 5 complexes (i.e., from the Hajdúsamson horizon) bracelets with 8-9 revolutions appeared (Bóna 1975, $100,101)$. Therefore, the idea has been expressed that lesser number of revolutions and a sharpened end are typical for early types (Bátora 2018, 178), and on this basis the Babino culture bracelets are relatively early. But it is impossible to clarify the chronology in this way, since the upper limiter in this case is the A2c phase, which is obviously late.

Neck rings found in the early Babino complexes (Lytoynenko, R. O. 2011, fig. 3:1-3, 10) are made of rod, and two are of twisted rod, and have curved ends (Fig. 1: 21, 24, 27). An identical neck ring from twisted rod was found in a burial of Voronezh culture in the Khokholsky cemetery (Pryakhin/ Sinyuk 1983). Twisted neck rings are typical in Europe from the end of the Tumulus culture and up to the Hallstatt period (Novotná 1984, 33). But they have morphological differences. From an early context, we know only one set from a 'hoard' in the settlement of Vel'ká Lomnica (Fig. 2: 25, 30, 34), 
which has been related to the late Baden culture. The 'hoard' included four neck rings from smooth rod and fragments of a twisted neck ring (all are exact analogues of the Babino neck rings), a chisel, rectangular plaques (with analogies in Vatya I and II) and an Early Bronze Age diadem. The dating basis was that the hoard was placed in a Baden vessel (Novotna 1984, 9, 12). But the unity of this 'hoard' is doubtful. The place of this settlement was used for cemetery and before this as arable land. Therefore, from the cultural layer $40-50 \mathrm{~cm}$ thick, only the lower part preserved and there are many damages. The hoard was found in 1896 by M. Greisinger, and was kept at his home for many years. After his death, the daughters gave the hoard to the Poprad Museum, and only then was the first time the idea has appeared that the hoard was in this vessel. But, judging by the archival photos, this vessel could not contain these neck rings, it was too small. Finally, the metal of the 'hoard' is represented by two chemical groups; both are typical of the EBA (see for more details Novotná/Soják 2013, 31, 33, 194, 196, 197). Above the Baden layer in this settlement are the layers of Hatvan culture and Otomani-Füzesabony komplexes. Therefore, judging by the presence of similar neck rings in the early Babino complexes, they belong to the Hatvan culture layer. ${ }^{3}$ This fact gives us the A1b and A1c periods, but in part both the earlier and the later periods.

In Europe, neck rings appeared from the very beginning of the EBA. In Slovakia, the earliest made of wire are present in the Chłopice-Veselé complexes, then in the early and classical Nitra culture (Fig. 2: 2), as well as in the transitional Nitra-Únětice phase. The earliest specimens are made of wire in one or two revolutions, some have curved ends. However, neck rings of wire are also found in Unětice culture burials of the Jelšovce cemetery, in complexes of the Hurbanovo type (Fig. 2: 17; Bátora 2000, 351; 2018, 175, 176; Novotná 1984, 14, 15; Podborský 2004, 188). In Slovakia, neck rings with a looped end appeared in the ProtoÚnětice culture, but massive neck rings with a thick middle part and ends curved into the loop are characteristic of the Únětice culture (A2a; Fig. 2: 11), and are absent in Madarovce culture (A2c; Bátora 2000, 321; 2018, 176, 177; Novotná 1984, pl. 81; Podborský 2004, 185, fig. 3). Babino culture objects can be considered as transitional between the first and second groups and attributed to the transition between the Nitra and Únětice cultures, i.e., the A1c period. In Hungary, neck rings with loop, very close to those of Babino culture, appeared in the Vatya Ib phase, but are also characteristic of the Vatya II phase. Similar to Babino neck rings were present in phases 1 and 2 of the Szőreg group, as well as in the Wieselburg culture. In the phase of Vatya II, massive neck rings appeared (Bóna 1975, $50,56,99,243,244)$. But one massive neck ring with looped ends is known from a burial of the Vatya I period (Vicze 2011, pl. 34). Therefore, the Hungarian parallels give us the most acceptable synchronization with period $\mathrm{A} 1 \mathrm{~b}-\mathrm{A} 2 \mathrm{a}$.

Glass-shaped pendants are well represented in the Babino, Abashevo and Voronezh complexes (Fig. 1: 22, 23, 28, 29; Lytoynenko, R. O. 2013, fig. 2: 13-15; Mimokhod 2012, 269; Pryakhin/Sinyuk 1983). In Slovakia, the earliest pendants appeared in the Unnetice culture, but then they are present in the later (relative to the discussed Eastern European) Mad'arovce culture and Otomani-Füzesabony complexes (Bátora 2018, 188; Chropovský 1960, 69, 70; Veliačik/Masnicová 2004, 177). Therefore, they are dated no earlier than phases A1c-A2a. In Hungary, these pendants are present in the complexes of the Wieselburg culture, from phases 1 and 2 of the Szöreg group, from the Vatya Ia phase and in the later Vatia II and III complexes, Wietenberg, the early Koszider horizon, Encrusted Ware and Tumulus cultures (Fig. 2: 31-33; Bóna 1975, 49, 50, 54, 69, 100, 185, 244; Vicze 2011). Therefore, for them, we also have only the lower date, not earlier than the phase of Vatya Ia.

Round hemispherical platelets with two holes are present in the Abashevo and early Lola and Voronezh cultures sites (Fig. 1: 36, 37, 48, 49; Mimokhod 2012, 180-182, 221). This is a common type of ornaments in Europe, which is found in burials of the Kisapostag, Vatya I cultures (since the phase Ia), Szőreg group (1 and 2; Fig. 2: 35; Bóna 1975, 49, 50, 54, 99; Vicze 2011, pl. 12; 22; 25; 27 etc.). But they are also present in the later complexes: Vatya III, Szőreg (phase 3), Perjamos-Gerjen, Füzesabony and Encrusted Ware cultures (Bóna 1975, 69, 99, 116, 159, 217; Dušek 1960, fig. 4). Therefore, using them the synchronization is possible with any period, starting from $\mathrm{A} 1 \mathrm{~b} / \mathrm{A} 1 \mathrm{c}$ and up to the end of the Central European EBA.

Abashevo culture diadems have close parallels in late Bell-Beaker complexes of the Oggau-Loretto type, but also in the Straubing and Únětice cultures (Fig. 2: 40; Chropouský 1960, fig. 25: 6, S. 69, 70). But similar diadems are known in the later complexes of Vatya II and III (Bóna 1975, 55, 69). Therefore, today we have a range within the entire EBA.

\footnotetext{
${ }^{3}$ It must be said that in her first publication M. Novotná (1967) defined these neck rings as belonging to the Hatvan culture, and only later she has changed this point of view.
} 


\section{Bone objects}

Bone awls are widespread in the Babino, early Lola and Sintashta complexes, as well as a number of other tools made of bone and antler. They are not a basis for dating, because they are typologically poorly expressed (bone used for a particular function was used), and in Europe they are found from the epi-Corded cultures to the end of the EBA, defining a wide range of dates within A0-A2 (Bátora 2000, 330, 363, 364; 2018, 194).

Bone arrowheads are found in the Lola, Abashevo and Sintashta complexes (Mimokhod 2012, 135-139). They are represented by diverse tanged, less often socketed objects. In Central Europe, bone arrowheads are also known, existing throughout the EBA (Bátora 2018, 198, 199; Bóna 1975, 102). Unfortunately, they are typologically rather amorphous and depend on the shape of the initial material. And, probably, R. A. Mimokhod is right, pointing to their Caucasian parallels (Mimokhod 2012, fig. 68).

Bone discs with a central hole are found in Lola and Sintashta cultures (Fig. 1: 13; Mimokhod 2012, 129-131). In Central Europe, flat bone discs with a hole are known in graves of Nitra-Únětice phase, Únětice, Unterwölbing, Adlerberg and Mad'arovce culture (Fig. 2: 51), in some instances with direct parallels in Sintashta culture (Bátora 2000, 364, 365, 366). Thus, they fall into the period A1b-A2a. In addition, this is a fairly simple object that could arise independently, or have southern Caucasian roots, since such things are not found in Babino culture sites.

Earlier I suggested analogies for the typical Babino and Lola culture round buckles with a central hole (Fig. 1: 12) in the Straubing, Unterwölbing and Adlerberg complexes (Fig. 2: 50), which allowed the Babino culture to be dated from the A1b phase (Grigoriev 2002, 136, 388-390). But, until a detailed typological comparison of many these objects is carried out, we have a wide range of dates within $\mathrm{A} 1 \mathrm{~b}-\mathrm{A} 2 \mathrm{a}$ phases. Variations of flat bone buckles with a central hole are also found in the Slovakian Únětice culture and in sites of the Szőreg group within phases 1-3 (Bátora 2018, 203; Bóna 1975, 102), which also fall into this interval.

It is necessary to reject the possibility of using the early Babino and Lola figured buckles with a hook (Fig. 1: 10, 11), for which parallels in Central Europe were offered. Similar objects were found in a VolskLbishche burial of the Southern Urals (Tamar-Utkul VII 4/3), the Abashevo culture of the Middle Volga, and in the Nurtai culture of Kazakhstan. The Nurtai buckle is identical to those in Ginchi, Lola, Khanlar in Transcaucasia, and can be considered as early (Lytoynenko, R. O. 2011, fig. 4; Mimokhod 2012, 120,
124, fig. 61; 2018, fig. 3). Nurtai complexes are a variant of Petrovka culture with an admixture of Alakul culture features. The formation of Alakul and Petrovka cultures begins soon after the formation of the Sintashta culture (Grigoriev 2016, 209), and in Kazakhstan we can expect an early manifestation of these stereotypes, but not earlier than the beginning of Sintashta culture. Accordingly, these finds indicate the synchronization of Ginchi, early Lola, Middle Volga Abashevo, Volsk-Lbishche, Sintashta and Nurtai complexes. This early penetration of Lola cultural components to the east is also marked by the discovery in the settlement of Toksanbay (with ware close to the Volsk-Lbische type) of the Lola ceramic ladle together with a disc-shaped cheek piece typical of the Sintashta and Petrovka cultures (Mimokhod 2012, 68). But European buckles are different. They are made of thin bone, have deep notches along the edges, and found in the later complexes of Madarovce-Věteřov and OtomaniFüzesabony (Fig. 2: 41, 42; Bátora 2018, 204). Therefore, they can reflect a late influence from Eastern Europe, and cannot be used to determine the lower boundary of Babino culture.

Pendants of shells and animal fangs are typical of Sintashta, Lola and Babino cultures (Fig. 1: 1, 41). Their origins were suggested in the Caucasus (Mimokhod 2012, 206). But the same set was typical in Europe. Shell pendants are present in epi-Corded cultures (Koštany and Nitra cultures), Únětice and Únětice-Mad’arovce burials, in the Szőreg group (phases 1-3), Vatya II (Bóna 1975, 103, 104; Chropovský 1960, 68; Vicze 2011, pl. 118; Vladár 1973, 153, Tab XIV; XV; XXXIII). Their possible date is period of A1a-A2b. Synchronization of pendants of animal fangs for which Central European parallels have been suggested (Lytoynenko, R. O. 2013, fig. 2: 20) has the same problem. They existed starting from the final Eneolithic, throughout the EBA, being well represented in the Únětice culture (Fig. 2: 36), later Füzesabony complexes, in all phases of the Szöreg group (Bátora 2000, 335, 366; 2018, 202; Bertemes/Heyd 2015, fig. 5; Bóna 1975, 86, 103; Chroporský 1960, 68; Jiráň 2008, fig. 1; Polla 1960, 337, fig. 15). Therefore, these objects do not have a dating potential.

\section{Stone objects}

Characteristic objects are stone wristguards from a bowstring. In Babino culture, these are the objects from long flat stone plates with carved grooves (Fig. 1: 17, 18), or holes, as in Krivaya Luka sites. Central European parallels in the Nitra and Unterwölbing complexes are suggested for them, although R. A. Mimokhod pointed also to their Near Eastern 
analogies (Lytvynenko, R. O. 2013, 122, fig. 3: 18, 19; Mimokhod 2012, 249, 250). In Slovakia, these objects (usually with holes at the ends) are present in the Nitra and Koštany cultures and in the older phase of Unětice culture, disappearing in the younger phase (Fig. 2: 45-47; Bátora 2018, 212; Jiráń 2008, fig. 1; Vladár 1973, 160, 161, 169). This means, they are typical for the early EBA phase, A1. In Hungary, similar objects are known in the period of Vatya culture phase $1 \mathrm{~b}$ and in the phases 1 and 2 of the Szöreg group (Bóna $1975,50,102)$, persisting possibly in phase A2a.

Arrowheads of Babino culture are represented by triangular-shaped objects with a hollow on the base, and for them European parallels have been also suggested (Fig. 1: 14; Lytoynenko, R. O. 2013, fig. 3; 4). For Sintashta and Lola cultures, arrowheads of this type are uncharacteristic. Therefore, the assumption of their penetration into Babino culture from Europe is quite reasonable. However, these arrowheads are too common and have wide dates (Fig. 2: 13, 18, 19): in Poland in the Bell-Beaker culture, then in Proto-Mierzanowice and Mierzanowice culture (Budziszewski/Włodarczak 2010, 49, fig. 12; Heyd 2007, 93), in Czechia in the early Únětice culture sites (Jiráň 2008, fig. 1), in Slovakia throughout the Nitra culture and in the Koštany culture, but their number decreases in Únětice culture (Bátora 2000, 328, 329; 2018, 213; Vladár 1973, 160, pl. II-IV). The presence of such arrowheads in the Unětice-Madarovce complexes (Vladár 1973, pl. XXXIII) makes it possible to determine a broad date within $\mathrm{A} 0-\mathrm{A} 2 \mathrm{~b}$.

\section{Faience objects}

In Eastern European cultures, simple beads (cylindrical and lenticular) are found, but more important for dating are beads with three or four protrusions, and in Babino, segmented beads are known (Fig. 1: 2-6, 45-47). Beads with protrusions are typical for late Catacomb culture monuments, the North Caucasus and Transcaucasia (early KayakentKharochoevo culture, Ginchi and Trialeti culture) and the Near East. Therefore, their southern origin is assumed (Lytvynenko, R. O. 2009, 16; Mimokhod 2012,191-193). Attempts on the basis of these objects to show the earlier chronological position of the Babino and Lola complexes relative to the Sintashta culture ones (Lytoynenko, R. A. 1999, 134) are probably inappropriate (for more details see Grigoriev 2018a, 43). In the Lola culture monuments, beads with three protrusions are found in graves of all stages, with rare beads with two and four protrusions. This is explained by the fact that this type of beads spread from the Caucasus, and the differences with the early Babino culture sets was caused by the territorial fashion, but not chronology. Beads with four protrusions were characteristic of late Catacomb period, and are found in Lola complexes only once, as in Sintashta (Mimokhod 2012, 191-198, $222,229)$. Thus, we see a situation identical to that of Sintashta, and, taking into account the presence of beads with four protrusions in the Sintashta cemetery of Tanabergen II, we can assume its early chronological position. And this suggests the synchronization of the early Sintashta culture with the late-Catacomb and Babino complexes.

In Central Europe, faience beads appeared at the very beginning of the EBA. In the Nitra culture there are disc-shaped beads, but there are also those with lens-shaped and conical cross-sections. Similar types are present in the Proto-Únétice and Únětice culture burials in Slovakia, in the late phase of the Bell-Beaker culture, the Unterwölbing, Straubing, Wieselburg, Koštany and Nagyrév cultures (Bátora 2000, 340; 2006, 194, 197, 199; 2018, 215, 217). In Hungary, in the Szöreg group, simple round and cylindrical faience beads are known in phases 1-3 (Fig. 2: 49; Bóna 1975, 104; Vicze 2011). Thus, this set has wide dates from A1a to A2a inclusive. Beads with four protrusions in Hungary are known in the graves of the Nagyrév and Vatya I, II cultures (Fig. 2: 48; Vicze 2011, pl. 6; 48; 104; 116), which corresponds to phases $\mathrm{A} 1 \mathrm{~b} / \mathrm{c}-\mathrm{A} 2 \mathrm{~b}$ and does not allow the date to be clarified. It is possible to narrow this date by means of segmented beads (Fig. 1: 3). This type of beads is present in the Slovakian Únětice, Nagyrév and Koštany cultures, but the earliest appeared in the Nitra-Unětice phase, then existing in the Otomani culture, and the two- and three-part beads are known in the Otomani-Füzeszabony complexes (Bátora 2000, 368; 2006, 199, fig. 138; 2018, 217; Bóna 1975, 159). Thus, this type of beads appeared, probably, in the A1c phase and existed until the end of the EBA. It is possible that, like the beads with protrusions, they also had southern origins. Analogs are available in Jericho (Kenyon 1965, fig. 25: 5).

\section{SYNTHESIS OF RESULTS}

Thus, from the above comparisons, we see that particular categories of artifact have wide ranges of existence. But some started a little later or later ended, which allows us to try to find a period in which all these types coexisted together (Table 2).

All the types are more concentrated within the phases A1b-A2a. But the only period of coexistence of all types discussed is the phase A1c. In the A1b phase, simpler wire types of neck rings are present, glass-shaped and faience segmented pendants are 
Table 2. The dating of the Central European parallels to Eastern European complexes.

\begin{tabular}{|c|c|c|c|c|c|c|c|c|c|}
\hline Types & $\begin{array}{c}\text { Late } \\
\text { Eneolithic }\end{array}$ & A0 & A1a & $\mathrm{A} 1 \mathrm{~b}$ & A1c & A2a & $\mathrm{A} 2 \mathrm{~b}$ & $\mathrm{~A} 2 \mathrm{c}$ & B \\
\hline Bipolar burials & • & • & • & • & • & • & - & - & - \\
\hline Applied cordons on ware & - & - & - & • & • & • & - & - & - \\
\hline Absence of ornaments in the form of willow leaf & - & - & - & - & • & - & • & • & • \\
\hline Simple rings of wire & • & • & • & • & • & • & • & • & - \\
\hline Spiral pendants & - & - & - & • & • & • & • & • & • \\
\hline Tube-shaped pendants & • & - & • & • & • & • & • & • & \\
\hline Grooved pendants in 1.5 revolutions & - & - & - & • & • & • & • & • & • \\
\hline Grooved pendants in 1.5 revolutions with a reverse loop & - & - & - & - & • & • & - & - & - \\
\hline Bracelets of wire & • & - & • & • & • & • & • & • & - \\
\hline Spiral finger rings and bracelets & • & $\cdot$ & • & • & • & • & • & • & - \\
\hline Short spiral bracelets & • & $\cdot$ & • & • & • & - & - & - & - \\
\hline Neck rings & - & - & • & • & • & • & - & - & - \\
\hline Glass-shaped pendants & - & - & - & - & • & • & • & • & - \\
\hline Hemispherical platelets with two holes & - & - & - & • & • & • & • & • & - \\
\hline Diadems & - & • & • & • & • & • & • & • & - \\
\hline Bone awls & $\cdot$ & $\cdot$ & • & • & • & • & • & • & - \\
\hline Bone discs with a central hole & - & - & - & • & • & • & - & - & - \\
\hline Bone buckles with a central hole & - & - & - & • & • & • & - & - & - \\
\hline Pendants of shells & - & - & - & - & - & - & - & - & - \\
\hline Pendants of animal fangs & $\cdot$ & • & • & • & • & • & • & - & - \\
\hline Stone wristguards & - & - & - & - & - & - & - & - & - \\
\hline
\end{tabular}

unknown. Grooved pendants in 1.5 revolutions are present in complexes from the phase A1b, but more likely from the phase A1c. This phase is indicated by pendants with reverse loop. From the phase A1c, spiral pendants spread wider. And for the phase A1b, ornaments in the form of willow leaf that did not appear in Eastern Europe were typical. In the A2a phase, massive types of neck rings dominate; stone wristguards are not typical; long spiral pendants and spiral bracelets are distributed. All this requires further studies, and some changes are possible. But while the most acceptable date is A1c.

\section{CHRONOLOGY}

Thus, taking into account the earlier publication (Grigoriev 2018b), we obtain synchronization of the Sintashta, Abashevo and Babino cultures and post-Catacomb formations with the Central European complexes of phases A1c-A2b. The validity of the lower boundary is confirmed by the fact that the radiocarbon dates of the Sintashta culture fall in the period 2010-1770 BC (Molodin/Epimakhov/Marchenko 2014), and the Nitra-Únětice phase (A1c) dates do in the period 1930-1870 BC (Bátora 2018, 89). There are earlier dates for Lola and Babino cultures within the $23^{\text {rd }}-18^{\text {th }}$ c. BC (Mimokhod 2011, 43, 48). They are formed by the old analyses in the Kiev laboratory, which gave this range for Sintashta, which was rejected (Epimakhov 2010, 50). In general, these are synchronous formations. To the arguments already cited (Grigoriev 2018a), we can add what we discussed above in relation to figured buckles and faience beads, and a number of other data.

R. A. Mimokhod has demonstrated the synchronization of Lola, Krivaya Luka and Babino cultures, as well as the fact that the three stages of Lola culture correspond to the three stages of Babino culture. Only in the Krivaya Luka group there is no stage corresponding to the third stage of Lola and Babino cultures, since in the area of its distribution monuments of the Pokrovsk type appeared (Mimokhod 2012, 216, 229, 233). Since they are later than Sintashta, we can admit synchronization of Sintashta with Lola and Babino cultures within their first stages.

In the cemetery of Kuptsyn-Tolga in Kalmykia, in a burial with the Lola culture rite (46/10) a Petrovka culture vessel was found (Mimokhod 2012, 279). Petrovka culture begins to form in the Sintashta culture time, but the penetration of its stereotypes to the south-west occurs in the post-Sintashta time (Grigoriev et al. 2018, 140, 141, 147), which may also indicate the synchronization of Sintashta and Lola cultures. 
More importantly, a direct correlation of post-Catacomb and Sintashta culture materials. According to V. V. Tkachev $(2007,231,232)$, in the Novy Kumak and Tanabergen II cemeteries, cases of later position of Late Catacomb burials relative to Sintashta culture ones were revealed. R. A. Mimokhod (2012, 234-235) suggests that it is more correctly to call the former 'post-Catacomb', and uses this data to prove the late position of Sintashta culture. But this stratigraphic situation is ambiguous, and points to the synchronization of these complexes (Grigoriev et al. 2018, 144, 145).

Most Lola knives inherited the Catacomb forms and existed within different stages of the culture (Mimokhod 2012, 81-90). And similar types, inherited the Eastern European patterns, are present in Sintashta culture (Grigoriev 2015, fig. 6-12). But there are two knives that indicate synchronization with early Lola culture. In Lola and Babino burials, pentagonal Catacomb knives are dated only to the $1^{\text {st }}$ stage. A similar knife is found in the Sintashta cemetery of Kamenny Ambar (Kostyukov/Epimakhov/ Nelin 1995, 201). The second is a long triangular knife with a middle rib and a sharp transition to the blade. This type was found in a complex of the developed stage of Lola culture (Mimokhod 2012, 81). A similar object was discovered in Sintashta culture (Bolshekaragansky cemetery; Grigoriev 2015, fig. 6-12: 13).

There is another possibility for synchronization. Early Lola burials were made in pits, catacombs, and deep pits with ledges. Sporadically there are collective and secondary or disarticulated burials. The last two types are not recorded for the middle period of Lola culture, and the late Lola burials were made exclusively in the pits (Mimokhod 2012, $220,223,226)$. By a combination of these signs, the Sintashta rite is comparable precisely to the early Lola rite.

Therefore, the date within the $20^{\text {th }} \mathrm{c}$. BC can be considered as a starting point for the formation of Babino, Sintashta, Abashevo, Lola, Krivaya Luka cultures, the appearance of circular fortified settlements in Hatvan culture and the beginning of stage A1c in Central Europe. Taking into account that radiocarbon dates are shifting toward historical ones, this date will shift. The beginning of Sintashta culture within the framework of the Near Eastern chronology is dated to the $19^{\text {th }} / 18^{\text {th }} \mathrm{c}$. BC (Grigoriev 2018a, 53). R. A. Mimokhod, based on the opinion of K. Kh. Kushnareva and R. O. Lytvynenko on the synchronization of the kurgan at Oshakan of the Karmirberd culture in Transcaucasia with the steppe block of chariot cultures, discusses an imported from Southern Mesopotamia necklace from faience, glass, agate beads and marine mollusks from the cemetery of Verin Naver of this culture. These beads belong to the Old Babylonian period, i.e. the $19^{\text {th }}-18^{\text {th }} \mathrm{c}$. BC, but he believes that it is possible to date to this time Sintashta and the late stage of Lola culture (Mimokhod 2012, 263, 264). But, taking into account a possibility of complete synchronization of the post-Catacomb groups and Sintashta culture, this date may be relevant for the start of phase A1c in Europe.

Unfortunately, it is impossible to verify it using dendrochronology, since the available data for the A1 period is limited. The dates from the burials of the classical phase of the Únětice culture (i.e., A2a) in Leubingen and Helmsdorf show 1942 and 1840 BC (Becker et al. 1989), which corresponds to radiocarbon dates from the earlier A1c phase. Therefore, the question of the absolute chronology of this period has not yet been resolved.

\section{RECONSTRUCTION OF THE PROCESS}

At the beginning of the A1c phase, we see a movement to the east in Central Europe: the Únětice culture penetrated from Moravia into Slovakia (Bátora 2018, 89). Slovak and German archaeologists suppose that there were some relations between the appearance of fortified settlements of Sintashta and Hatvan cultures (Bátora 2018, 230; Lichardus/Vladár 1996, 39-43). The latter culture was formed at the beginning of the EBA, but in the early circle of fortifications at the Vráble settlement, materials of the Hatvan and Únětice cultures have been revealed when the Únětice culture movement to the east occurred (Bátora et al. 2012; Točík 1986). On the other two fortified settlements (Včelince and SantovkaMadarovce), pieces of the early Hatvan culture ware were found, but these were finds from the surface, and on the fortified settlements, the Hatvan culture ware was represented by ceramics of its younger phase (Bátora 2018, 229).

As a result, we have a complex process, starting with two impulses, with the interaction of different components and microprocesses. About the interaction of these two impulses penetrated into the North Pontic area settled by the Catacomb culture people, wrote R. O. Lytoynenko $(2009,62,65)$, explaining this by climate change, but this process covered vast spaces from Central Europe to the Transurals. The first impulse was the Sintashta culture migration from the Near East. Its synchronism with the appearance of Hatvan culture fortifications allows us to assume that this was somehow connected, and a part of this impulse reached Slovakia. It is necessary to note the difference of this process in the Transurals and Slovakia. Prior to this, in the first region, there were no Bronze 
Age cultures, so the Sintashta culture had not been so strongly transformed, many of its components have Near Eastern prototypes. In Central Europe, this impulse penetrated in the area with developed culture. As a result, fundamental changes in the Hatvan culture did not occur.

The former Catacomb-Poltavka people of Eastern Europe were included in the migration. But to a greater extent it affected the Petrovka and early Alakul complexes on the northern or eastern Sintashta periphery. In the Eastern European steppe, in this period, there was a transformation of Catacomb cultures, with the formation of the block of post-Catacomb groups (Lola, Krivaya Luka), in whose formation the local Catacomb and Caucasian components prevailed. And it is significant that of all the discussed parallels there are those in Lola and Sintashta cultures for which the southern origins can be assumed. Objects of Central European origins in Sintashta culture are completely absent, and in Lola culture it is permissible for single finds of spiral pendants and platelets with two holes.

The second impulse from Central Europe to the east involved components originating from the Bell-Beaker culture, which had a decisive influence on the formation of the Abashevo culture (with participation of the local Fatyanovo culture people, who had earlier Central European roots) and the epi-Corded cultures formed the Babino culture (with participation of the local Catacomb culture component) and, possibly, influenced the appearance of the Voronezh culture. At the same time, we see the interaction of these impulses, and new cultural developments, which makes it difficult to create an adequate chronological scheme, but explains the appearance of objects with Caucasian roots in Central Europe, and Central European ones in Eastern Europe. ${ }^{4}$

\section{BIBLIOGRAPHY}

Bátora 1983 - J. Bátora: Záver eneolitu a začiatok doby bronzovej na východnom Slovensku. Historica Carpatica 14, 1983, 169-227.

Bátora 2000 - J. Bátora: Das Gräberfeld von Jelšovce. Ein Beitrag zur Frühbronzezeit im nordwestlichen Karpatenbecken. Kiel 2000.

Bátora 2006 - J. Bátora: Štúdie ku komunikácii medzi strednou a východnou Európou v dobe bronzovej. Bratislava 2006.

Bátora 2018 - J. Bátora: Slovensko v staršej dobe bronzovej. Bratislava 2018.

Bátora/Furmánek/Veliačik 2004 -J. Bátora/V. Furmánek/L. Veliačik (Hrsg.): Einflüsse und Kontakte Alteuropäischer Kulturen. Festschrift für Jozef Vladár zum 70. Geburtstag. Nitra 2004, 165-181.

Bátora et al. 2012 - J. Bátora/A. Behrens/J. Gresky/M. Ivanova/K. Rassmann/P. Tóth/K. Winkelmann: The Rise and Decline of the Early Bronze Age Settlement Fidvár near Vráble, Slovakia. In: J. Kneisel (ed.): Collapse or Continuity? Environment and Development of Bronze Age Human Landscapes. Bonn 2012, 111-129.

Becker et al. 1989 - B. Becker/K.-D. Jäger/D. Kaufmann/ Th. Litt: Dendrochronologische Datierungen von Eichenhölzern aus den frühbronzezeitlichen Hügelgräbern bei Helmsdorf und Leubingen (Aunjetitzer Kultur) und an bronzezeitlichen Flußeichen bei Merseburg. Jahresschrift für mitteldeutsche Vorgeschichte 72, 1989, 299-312.

Bertemes/Heyd 2015 - F. Bertemes/V. Heyd: 2200 BC - Innovation or Evolution? The genesis of the Danubian Early Bronze Age. In: H. Meller/H. W. Arz/R. Jung/R. Risch (Hrsg.): Tagungen des Landesmuseum für Vorgeschichte 12. Halle 2015, 1-18.
Bóna 1975 - I. Bóna: Die Mittlere Bronzezeit Ungarns und Ihre Südöstlichen Beziehungen. Budapest 1975.

Budziszewski/Włodarczak 2010 - J. Budziszewski/P. Włodarczak: Kultura pucharów dzwonowatych na Wyżynie Małopolskiej. Kraków 2010.

Chropovský 1960 - B. Chropovský: Gräberfeld aus der älteren Bronzezeit in Vel'ký Grob. In: Chropovský/Dušek/ Polla 1960, 14-138.

Dresely 2004 - V. Dresely: Schnurkeramik und Schnurkeramiker im Taubertal. Stuttgart 2004.

Dušek 1960 - M. Dušek: Patince - das Gräberfeld der Nordpannonischen Kultur. In: Dušek/Polla 1960, $139-298$

Epimakhov 2010 - A. V. Epimakhov: Sintashtinskaya radiokarbonnaya khronologiya. In: D. G. Zdanovich (red.): Arkaim-Sintashta. Drevnee nasledie Yuzhnogo Urala 2. Chelyabinsk 2010, 49-51.

Furmánek/Veliačik/Vladár 1999 - V. Furmánek/L. Veliačik/ J. Vladár: Die Bronzezeit im Slowakischen Raum. Rahden/ Westf. 1999.

Grigoriev 2002 - S. A. Grigoriev: Ancient Indo-Europeans. Chelyabinsk 2002.

Grigoriev 2015 - S. Grigoriev: Metallurgical Production in Northern Eurasia in the Bronze Age. Oxford 2015.

Grigoriev 2016 - S. A. Grigoriev: Problema Khronologii i proiskhozhneniya alakul'skoy kul'tury v svete novich raskopok v Juzhnom Zaurale. Vestnik arkheologii, antropologii, etnografii 3, 2016, 44-53.

Grigoriev 2018a - S. A. Grigoriev: Problema Khronologii sintashtinskoy kulturi. In: D. G. Zdanovich (red.): Stejnaya Evraziya v epokhu bronzi. Kul'turi, idei, tekhnologii. Chelyabinsk 2018, 37-61.

\footnotetext{
4 Acknowledgments: This study was possible thanks to the support of the Slovak Agency for Academic Information. And I would like to express my gratitude to colleagues who discussed the draft: Professors Jozef Bátora (Comenius University Bratislava and Archaeological Institute of the Slovak Academy of Sciences Nitra) and Roman Lytoynenko (Donetsk University at Vinnitsa).
} 
Grigoriev 2018b - S. A. Grigoriev: Eastern influences and the transition to new types of metalworking at the end of the Early Bronze Age in Central Europe. Musaica archaeologica 2, 2018, 33-49.

Grigoriev et al. 2018 - S. A. Grigoriev/L. Yu. Petrova/M. L. Pleshanov/E. V. Gushchina/Yu. V. Vasina: Poselenie Mochishche i andronovskaya problema. Chelyabinsk 2018.

Heyd 2004 - V. Heyd: Soziale Organisation im 3. Jahrtausend v. Chr. entlang der oberen Donau. Der Fall Schnurkeramik und Glockenbecher. Das Altertum 49, 2004, 183-215.

Heyd 2007 - V. Heyd: When the West meets the East: The Eastern Periphery of the Bell Beaker Phenomenon and its Relation with the Aegean Early Bronze Age. In: I. Galanaki/Y. Galanakis/R. Laffineur/H. Tomas (eds.): Between the Aegean and Baltic Sees. Prehistory across borders. Zagreb 2007, 91-104.

Chropovský/Dušek/Polla 1960 - B.Chropovský/M. Dušek/ B. Polla: Pohrebiská zo staršej doby bronzovej na Slovensku I. Bratislava 1960.

Jaeger/Kulcsár 2013 - M. Jaeger/G. Kulcsár: Kakucs-Balladomb. A case study in the absolute and relative chronology of the Vatya culture. Acta Archeologica Academiae Scientiarum Hungricae 64, 2013, 293-324.

Jiráň 2008 - L. Jiráň (ed.): Archeologie pravěkých Čech 5. Doba bronzová. Praha 2008.

Kenyon 1965 - K. M. Kenyon: Excavations at Jericho. Volume II. Jerusalem 1965.

Kiss et al. 2015 -V. Kiss/S. Fábián/T. Hajdu/K. Köhler/G. Kulcsár/I. Major/G. Szabó: Contributions to the Relative and Absolute Chronology of the Early and Middle Bronze Age in Western Hungary Based on Radiocarbon Dating of Human Bones. In: R. E. Németh/ R. Botond (eds.): Bronze Age Chronology in the Carpathian Basin. Proceedings of the International Colloquium from Târgu Mureş, 2-4 October 2014. Cluj-Napoca 2015, 23-36.

Kostyukov/Epimakhov/Nelin 1995 - V. P. Kostyukov/A. V. Epimakhov/D. V. Nelin: Novyi pamyatnik sredney bronzy v Yuzhnom Zaurale. In: I. B. Vasiljev (red.): Drevnie indoiranskie kultury Volgo-Uralya (II. tys. do n. e). Samara 1995, 156-207.

Lytoynenko, R. O. 2009 - R. O. Lytvynenko: Geneza, rozvytok ta istorichna dolya kultturnogo kola Babine. In: C. M. Sanzharov (red.): Materialy ta doslidzhennia z arkheologiyi Skhidnoy Ukrainy. Vid neolitu do kimmeriytsiv. Lugansk 2009, 44-90.

Lytvynenko, R. O. 2011 - R. O. Lytvynenko: Metalovyrobnytstvo plemen Dnipro-Donskoyi babynskoyi kultury. Visnyk Donetskogo natsionalnogo universytetu 2, 2011, 146-175.

Lytvynenko, R. O. 2013 - R. O. Lytvynenko: Central European parallels to the Dnieper-Don centre of Babyno
Culture. Bultic-Pontic studies 18, 2013, 121-138.

Metzinger-Schmitz 2004 - B. Metzinger-Schmitz: Die Glockenbecherkultur in Mähren und Niederösterreich. Saarbrücken 2004.

Mimokhod 2011 - R. A. Mimokhod: Radiouglerodnaya khronologiya bloka postkatakombnykh kul'turnykh obrazovaniy. Kratkie soobshcheniya Instytuta arkheologii 225, 2011, 28-53.

Mimokhod 2012 - R. A. Mimokhod: Lolinskaya kultura. Severo-zapadnyj Prikaspiy na rubezhe srednego i pozdnego periodov bronzovogo veka. Moskva 2013.

Mimokhod 2018 - R. A. Mimokhod: Paleoklimat i kul'turogenez v Vostochnoy Evrope v kontse III tys. do n. z. Rossiyskaya arkheologiya 2, 2018, 33-48.

Molodin/Epimakhov/Marchenko 2014 - V. I. Molodin/A. V. Epimakhov/Zh. V. Marchenko: Radiouglerodnaya khronologiya kultur epokhi bronzy Urala i Yuga Zapadnoy Sibiri: printsipy i podkhody, postizheniya i problemy. Vestnik Novosibirskogo universyteta 13/3, 2014, 136-167.

Neugebauer 1991 - J.-W. Neugebauer: Die Nekropole F von Gemeinlebarn, Niederösterreich. Mainz am Rhein 1991.

Novotná 1967 - M. Novotná: Ein Depot getriebenen Bronzen von der Höhensiedlung Burchbrich in Vel'ká Lomnica (slowakische Zips). Acta Archaeologica Carpathica 9, 1967, 63-68.

Novotná 1984 - M. Novotná: Halsringe und Diademe in der Slowakei. Prähistorische Bronzefunde XI/4. München 1984.

Novotná/Soják 2013 - M. Novotná/M. Soják: Vel'ká Lomnica-Burchbrich. Urzeitliches Dorf unter der Hohen Tatra. Nitra 2013.

Peška 2005 - J. Peška: Protoúnĕtické pohřebištĕ z Pavlova. Olomouc 2005.

Podborský 2004 - V. Podborský: Nové nálezy kovových nákrčníků v hrobech $\mathrm{z}$ doby bronzové na Moravě a jejich význam. In: Bátora/Furmánek/Veliačik 2004, 185-198.

Polla 1960 - B. Polla: Birituelle Füzesabonyer Begräbnisstätte in Streda nad Bodrogom. In: Chropovský/Dušek/Polla 1960, 299-386.

Pryakhin/Sinyuk 1983 - A. D. Pryakhin/A. T. Sinyuk: Kurgan epokhi bronzy u pos. Khokhol'skiy. Sovetskaya arkheologya 3, 1983, 197-202.

Tkachev 2007 - V. V. Tkachev: Stepi Yuriuralya i Zapadnogo Kazakhstana na rubezhe epokh sredney i pozdney bronzy. Aktove 2007.

Točík 1986 - A. Točík: Opevnené sídlisko zo staršej doby bronzovej vo Vrábloch. Slovenská archeológia 34, 1986, 463-476.

Veliačik/Masnicová 2004 - L. Veliačik/S. Masnicová: Výsledky antropologickej analýzy pohrebiska únĕtickej kultúry v Rumanovej. In: Bátora/Furmánek/Veliačik 2004, 165-181.

Vicze 2011 - M. Vicze: Bronze Age Cemetery at DunaújvárosDuna-dülö. Budapest 2011.

Vladár 1973 - J. Vladár: Pohrebiská zo staršej doby bronzovej v Branči. Bratislava 1973. 


\title{
Stredoeurópske impulzy do východnej Európy vo včasnom druhom tisícročí pred n. 1 .
}

\author{
Stanislav Grigoriev
}

\begin{abstract}
SÚHRN
Od úplného začiatku doby bronzovej vidno interakciu medzi kultúrami strednej Európy a ich východnými susedmi. Najznámejšia je migrácia kmeňov jamovej kultúry do Európy v 3. tis. pred n. 1. Ďalšou epizódou bol prienik východoeurópskych a uralských zložiek do Európy v období stupňa A2b. Tento príspevok sa venuje procesu spätných európskych impulzov do Východnej Európy, ktoré sa objavili v staršej fáze staršej doby bronzovej a viedli k vzniku niektorých kultúr, ktoré sa v Eurázijskej periodizácii vztahujú k prechodnému obdobiu medzi strednou a mladšou dobou bronzovou. Tieto impulzy poskytujú možnost' chronologického porovnania európskych a východných kultúr tohto obdobia, vrátane tých, ktoré neboli priamo zapojené do predmetného procesu: Babino, Lola, Voronež, Abaševo a Sintašta.

Predložená analýza je založená na porovnaní pohrebného rítu a 25 typov artefaktov. Žial,' väčšina objektov v strednej Európe má široký chronologický rámec, nie sú teda vhodné na podrobné datovanie. Spravidla ani nepokrývajú celú dobu bronzovú. Často sa jednotlivé typy artefaktov začínajú používat trochu neskôr alebo sa, naopak, prestávajú používat’ o niečo skôr. Sumarizácia týchto dát ukázala, že najbežnejšie sa objekty koncentrujú v rámci fáz A1b - A2a. Avšak jediným obdobím, ked’ sa všetky predmetné typy vyskytujú súčasne, je fáza A1c. Včasné stupne skúmaných kultúr východnej Európy možno teda datovat do tohto obdobia.

Charakter skúmaných paralel je vel'mi zaujímavý. Pohrebný rítus kultúry Babino je podobný európskemu,

primárne rítu kultúr epišnúrového komplexu, čo umožňuje učinit’ záver o migrácii niektorých epišnúrových skupín a ich účasti na formovaní kultúry Babino. Európske paralely sú predovšetkým prítomné v kultúrach Babino, Abaševo a čiastočne aj Voronež. V kultúre Lola na stepiach severne od Kaukazu sú zriedkavé a v kultúre Sintašta absentujú. Spoločné črty v kultúrach Lola, Sintašta a v kultúrach strednej Európy vyplývajú z artefaktov pochádzajúcich južne od Kaukazu.

Vzorec rozšírenia spoločných znakov je vysvetlený osobitostami v kultúrnom vývoji v tomto období. V tom čase prebiehali v rozsiahlych oblastiach od strednej Európy po Ural dva procesy. Prvý je spojený s migráciou z Blízkeho východu, čo vyústilo do vytvorenia kultúry Sintašta na Urale. Tento presun prestahoval niektoré zakaukazské skupiny do východoeurópskej stepi, kde sa sformovali mladšie katakombové kultúry a objavili sa post-katakombové kultúry (Lola, Krivaja Luka). Čast’ týchto impulzov pravdepodobne zasiahla Slovensko a Mad’arsko, kde sa v hatvanskej kultúre objavili opevnené kruhové osady podobné tým v kultúre Sintašta. $\mathrm{V}$ tom istom čase sa odohrávala migrácia zo strednej Európy na východ. V jej dôsledku vznikli kultúry Babino, Voronež a Abaševo.

Synchronizáciu kultúr fázy A1c zo strednej Európy so skúmanými východnými kultúrami potvrdila aj zhoda rádiokarbónových dát $\mathrm{v}$ rámci 20.-19. stor. pred n. 1. Ak sa však aplikuje blízkovýchodná chronológia, ich začiatok sa posunie do 19. až 18. stor. pred n. 1 .
\end{abstract}


